\author{
ADAM WIELOMSKI \\ Uniwersytet Kardynała Stefana Wyszyńskiego \\ Wydział Prawa i Administracji
}

\title{
Geneza antropologii politycznej Carla Schmitta
}

Zwolennicy pesymistycznej antropologii nauczają, że człowiek rodzi się zły lub takim staje się $\mathrm{w}$ ciągu swojego życia. Jest namiętny i irracjonalny. Jest egoistą i nie brzydzi go przemoc. Chrześcijanie twierdzą, że został skażony grzechem pierworodnym, który trwale zmienia jego naturę. Badacz doktryn polityczno-prawnych jest świadomy, że u zdecydowanej większości myślicieli politycznych taka konstatacja prowadzi do krytyki liberalizmu oraz wolności indywidualnych i - konsekwentnie - do pochwały władzy autorytarnej. Jak zauważa Thomas Molnar, analizując konserwatywną myśl polityczną jako taką: „z punktu widzenia politycznego doktryna o grzechu pierworodnym jest dogłębnie antyrewolucyjna" 1 .

Do najwybitniejszych przedstawicieli pesymistów antropologicznych zajmujących się systematyczną refleksją nad państwem i prawem w XX w. z pewnością należał Carl Schmitt, którego antyliberalna koncepcja polityki została wyłożona w Pojęciu polityczności (1927) ${ }^{2}$. Celem tego tekstu nie jest omówienie tej niewielkich rozmiarów rozprawki, gdyż w literaturze czyniono to już wielokrotnie. Po przypomnieniu pokrótce jej głównych tez oraz krytyki liberalizmu tego myśliciela chciałbym zabrać głos $\mathrm{w}$ debacie na temat doktrynalnej genezy pesymistycznej antropologii politycznej tego prawnika. Na ten temat w literaturze przedmiotu nadal bowiem trwają kontrowersje.

1 T. Molnar, The Decline of the Intelectual, Cleveland 1961, s. 175.

2 C. Schmitt, Pojęcie polityczności, [w:] idem, Teologia polityczna i inne pisma, Kraków 2000, s. 191-250. 


\section{Krytyka antropologii i państwa liberalnego}

W 1927 r. Carl Schmitt publikuje Pojęcie polityczności. Rüdiger Altmann uważa, że to jego „najbłyskotliwszy esej”3, ale Łukasz Święcicki szybko gasi radość biorącego w ręce tę małą książeczkę czytelnika, przypominając, że to ,jeden z najtrudniejszych, najbardziej abstrakcyjnych i skomplikowanych tekstów"4 tego myśliciela. Bez wątpienia dzieło jest skierowane przeciwko weimarskiej liberalnej demokracji i jej nierozumieniu zjawiska polityczności. Na jego stronach - oraz w wielu innych pismach - Schmitt stawia liberalizmowi liczne zarzuty:

1) Liberalizm uznaje prymat i dobro jednostki nad dobrem wspólnym, którego strażnikiem jest państwo. Naród jest traktowany jako prosta suma interesów indywidualnych, co uniemożliwia sformułowanie i realizację doktryny racji stanu.

2) Liberalizm nie jest zdolny do wykrzesania wrogości pomiędzy grupami ludzkimi, gdyż liberalna koncepcja człowieka i państwa zakłada pacyfizm i niekonfliktowość, zastąpienie wojen zewnętrznych przez handel, a wewnętrznych — przez wolne wybory.

3) Liberałowie kierują się humanistyczną ideologią wyrosłą z tradycji rewolucji francuskiej. Nie rozumieją polityki, gdzie rządzi przemoc, której celem jest obrona lub zmiana istniejącego podziału dóbr. Łudzą się, że prawo może ją skutecznie zastąpić. W ślad za tym idzie bezdecyzyjność. Doktryna państwa prawnego uniemożliwia sprawne reagowanie polityczne.

4) Skoro liberalne państwo nie posiada zdolności do samoobrony w sytuacjach kryzysowych, to antyszambruje socjalizmowi demokratycznemu (SPD) lub rewolucyjnemu (leninizm). Państwo liberalne nie posiada woli politycznej delegalizacji partii skrajnych i jest bezradne wobec zwycięstwa wyborczego radykałów. Jest bezbronne, ponieważ nie wierzy samo w siebie i we własną prawomocność.

5) Państwo liberalne jest słabe, gdyż jego instytucje podporządkowane są prawu mającemu chronić własność. Silne państwo mieszczanie kojarzą z despotyzmem i wysokimi podatkami, nie rozumiejąc, że dziś zagrożeniem jest dla nich nie monarchia, lecz demagogiczna lewica ${ }^{5}$.

${ }^{3}$ R. Altmann, Analytiker des Interims. Wer war Carl Schmitt, was ist von ihm geblieben?, [w:] Carl Schmitt und die Liberalismuskritik, red. H. Lietzmann, K. Hansen, Opladen 1988, s. 32.

4 Ł. Święcicki, Przyjaciel czy wróg? Ernst Jünger w perspektywie „Pojęcia polityczności” Carla Schmitta, [w:] Ernst Jünger (1895-1998). Bojownik, robotnik, anarcha, red. W. Chołostiakow, J. Michalczenia, Olsztyn 2013, s. 121.

${ }^{5}$ K. Hansen, Feindberührungen nur versöhnlichen Ausgang. Carl Schmitt und der Liberalismus, [w:] Carl Schmitt und die Liberalismuskritik..., s. 9-12; G. Maschke, Drei Motive im Anti-Liberalismus Carl Schmitts, [w:] Carl Schmitt und die Liberalismuskritik..., s. 55-75; M. Gralher, Antinomisches Denken und dilemmatische Kontrastdialektik. Warum Carl Schmitt kein Liberaler sein konnte, [w:] Carl Schmitt und die Liberalismuskritik..., s. 81-91; B. Tucker, Der Ausnahmezustand. An den Grenzen von Aufklärung und Liberalismus, [w:] Carl Schmitt und die Liberalismuskritik..., s. 99-101. 
Carl Schmitt uważa, że u źródeł liberalizmu znajduje się błąd fundamentalny, a mianowicie twierdzenie antropologiczne, że człowiek z natury rodzi się i pozostaje dobry oraz racjonalny, więc nie potrzebuje karzącego państwa, wyposażonego w zinstytucjonalizowaną przemoc. Dlatego liberał nie rozumie i nie dostrzega walorów oraz konieczności stworzenia silnego i autorytarnego państwa.

Pojęcie polityczności to rozprawka napisana jako polemika wobec liberalnej teorii polityczności, polemiczna z perspektywy pesymistycznej i realistycznej, gdzie polityka postrzegana jest jako permanentny konflikt konfesyjny we wczesnej Nowożytności, który na przełomie XIX-XX w. przekształcił się w ideologiczny. Zwolennik pesymistycznej antropologii państwo pojmuje jako koniecznego pacyfikatora sporów i waśni grożących wybuchem wojny domowej ${ }^{6}$.

W eseju Carla Schmitta centralnym pojęciem jest suwerenne państwo, połączone z konstatacją, że ten tradycyjny monopolista polityczności ulega postępującej dezintegracji. Schmitt twierdzi, że żyjemy w epoce, gdy zaczyna się przypisywać stronnictwom atrybut polityki, czyli uprawnienie wyznaczania wroga publicznego. W tej sytuacji „państwo traci znaczenie jako jedność polityczna”7. W jego miejsce nowymi podmiotami politycznymi stają się partie i grupy partykularne, podczas gdy państwo spada do rangi miejsca starcia pomiędzy nimi, gdzie obywatele zaczynają się utożsamiać bardziej z partią polityczną niż z własnym państwem. Gdy proces ten ma charakter powszechny, terytorialna organizacja etatystyczna rozpada się, a nowymi punktami odniesienia, nowymi centrami lojalności, stają się partykularne stronnictwa.

Beneficjantami tego procesu są nowe podmioty polityczne znajdujące się wewnątrz państwa: totalitarne partie polityczne i rewolucyjne klasy społeczne. Szczególnie niebezpieczne są te nowo powstałe podmioty, które wykonują rozkazy przychodzące z zewnątrz, zza granicy. Podmiotem takim są partie komunistyczne ulokowane wewnątrz tradycyjnych państw, ale kierowane centralnie z Moskwy ${ }^{8}$. Czyli tradycyjny podmiot polityczności (państwo) jest wypierany przez podmiot z jednej strony szerszy od niego (internacjonalistyczny), a z drugiej strony węższy, gdyż na terenie tradycyjnych jednostek politycznych skupiających

6 J.E. Dotti, Estado, Representación, Guerra. Algunas consideraciones sobre la concepción Hobbesiano-Schmittiana de lo político, „Revista de Ciencias Sociales” 2012, nr specjalny: Carl Schmitt: Análisis Crítico, s. 437-470; H. Brunkhorst, Der Leviathan und die Intellektuellen. Carl Schmitts theologisches Missverständnis des Politischen, [w:] Les Intellectuels et l'Etat sous la République de Weimar, red. M. Gangl, H. Roussel, Paris 1993, s. 73-87.

7 C. Schmitt, op. cit., s. 203.

8 M. Nicoletti, Transcendenza é potere. La teologia politica di Carl Schmitt, Brescia 1990, s. 308-309; H. Ottmann, „Das Zeitalter der Neutralisierungen und Entpolitisierungen”. Carl Schmitts Theorie der Neuzeit, [w:] Carl Schmitt. Der Begriff des Politischen. Ein kooperativer Kommentar, red. R. Mehring, Berlin 2003, s. 156; G. Balakrishnan, L'ennemi. Un portrait intellectuel de Carl Schmitt, Paris 2006, s. 16-17, 147-454; J.P. McCormick, Educable or Sinflul Evil? Revisting the Moral Status of the Political in the Schmitt-Strauss Exchange, [w:] The Problem of Political Theology, red. A. Gornisiewicz, P. Armada, K.C. Matuszek, Kraków 2012, s. 181. 
tylko część obywateli (proletariat), którzy tworzą zorganizowaną i zdyscyplinowaną partię polityczną, reprezentującą interesy klasowe, mającą ośrodek kierowniczy poza terytorium państwa.

W literaturze przedmiotu wskazuje się, że Pojęcie polityczności stanowi odpowiedź na myśl i dzieło Władimira Lenina. Schmitt jest teoretykiem podmiotowości politycznej państwa narodowego, podczas gdy Lenin — teoretykiem podobnej podmiotowości partii komunistycznych ${ }^{9}$. W tej kwestii niemiecki prawnik wyraża tradycyjne w niemieckiej prawicy przekonanie, że polityka powinna zostać usunięta z wnętrza państwa, gdzie winno ją zastąpić ,administrowanie” (za pośrednictwem urzędników), i ograniczać się (w sytuacji idealnej) do polityki zagranicznej. Polityka powinna wyczerpywać się w stosunkach międzynarodowych ${ }^{10}$.

Carl Schmitt twierdzi, że po rewolucjach w Rosji z lutego i października 1917 r. oraz w Niemczech z listopada 1918 r. państwo ponownie musi odzyskać monopol na wyznaczanie wrogów i prowadzanie przeciwko nim skutecznej mobilizacji politycznej (militarnej, ekonomicznej, propagandowej). Przypomina, że cechą tradycyjnego podziału politycznego jest narodowościowy (obywatelski) charakter tej opozycji: Niemcy versus Francuzi lub Niemcy versus Rosjanie. Państwo dzieli ludzi na narody zorganizowane politycznie, a nie na skonfliktowane klasy w obrębie narodów.

Pesymistyczna antropologia to punkt wyjścia Schmittowskiego frontalnego ataku na ideologię i państwo liberalne. Schmitt uważa, że optymistyczna antropologia liberałów prowadzi ich do stanowiska, iż państwo powinno być maksymalnie ograniczone, aksjologicznie agnostyczne, biernie przyglądające się, jak jednostki i grupy toczą (pokojowe) dysputy, wzajemnie szanując przy tym swoje przyrodzone uprawnienia, używając $\mathrm{w}$ tych dyskusjach pokojowej i racjonalnej perswazji. Wynikiem takiej debaty są co kilka lat ponawiane wybory parlamentarne, w których wybierani są ludzie cechujący się szczególnymi przymiotami intelektualnymi i etycznymi. Ale to tylko fałszywa teoria zbudowana na fałszywej antropologii! Rzeczywistość jej zaprzecza. Ludzie wcale nie są racjonalni i nie posługują się argumentami, lecz demagogią socjalną. Państwo liberalne jest słabe i rozrywane konfliktami, niezdolne do unicestwienia komunizmu. Filozofia polityczna liberalizmu i pochodna mu nauka o państwie nie jest zdolna ukonstytuować trwałego i stabilnego porządku politycznego.

W okresie weimarskim Carl Schmitt uważał państwo liberalne za formę przejściową i chwilową pomiędzy absolutyzmem sprzed 1789 r. a nowymi typami państw (komunizm, faszyzm, dyktatury). Przejściowość tego typu państwa

${ }^{9}$ M. Garcia-Pelayo, Idea de la política, Caracas 1968, s. 10-14; C. Herrera, Carl Schmitt y el marxismo. Puntos de encuentro y de ruptura en la noción de realismo político, „Res Publica” 1998, nr 2, s. 35-68.

10 R. Baumert, Carl Schmitt contre le parlementarisme weimarien. Quatorze ans de rhétorique réactionnaire, „Revue française de Science Politique” 2008, nr 58, s. 27-28; M. Garcia-Pelayo, op. cit., s. 12. 
miała wynikać z faktu, że współcześni mu liberałowie nie byli zdolni zbudować i obronić stabilnego porządku politycznego. W jego oczach liberalizm to nie tylko utopia ideologiczna. Jego zwolennicy reprezentują pewien typ psychologiczny, charakteryzujący się niezdolnością do podejmowania radykalnych decyzji politycznych w dramatycznych okolicznościach - liberałowie dyskutują, negocjują, obradują, ale nie podejmują decyzji, nawet gdy są zagrożeni rewolucją bolszewicką. Gdy ta wybucha, liberał dyskutuje i obraduje, zamiast podjąć decyzję o unicestwieniu jej, a następnie ją zrealizować za pomocą wojska ${ }^{11}$.

W zarysowanej powyżej krytyce liberalizm to niepolityczny pogląd na świat, wyrastający z fałszywej optymistycznej antropologii — oto esencja krytyki liberalizmu Schmitta. Liberalizm jest wizją wyłącznie krytyczną, której brakuje holistycznej wizji pozytywnej, czyli mobilizującej społeczeństwo religii, mitu politycznego lub ideologii, które jako jedyne mogą je scalić, wskazując mu wrogów i ucząc nienawiści. Zdaniem Schmitta wspólnota nie jest zdolna istnieć bez nienawiści wobec „obcego” usytuowanego „na zewnątrz”. Gdy brak jej wroga zewnętrznego, konflikty wybuchają „,wewnątrz”, wedle podziałów konfesyjnych lub klasowych. Nie należy tego faktu oceniać pozytywnie lub nagannie, lecz przyjąć go jako dany, wynikły z natury ludzkiej. Ludzie są bowiem istotami społecznymi, których tożsamość wyrażają religie i ideologie, żywią się nienawiścią do innych grup, do „obcego”. Państwa liberalne próbują zaprzeczyć tej prawdzie społecznej, dlatego są wydane na łup grup zdeterminowanych do działania i napędzanych przez fanatyczne religie i ideologie uczące nienawiści do liberalizmu. Najniebezpieczniejszą z nich we współczesnej epoce jest komunizm.

Według Carla Schmitta polityczność wynika z faktu, że grupy ludzkie spierają się o interesy, a nie mogąc dojść do zgody, prowadzą ze sobą spory, a nawet wojny. Dlatego ogląd empiryczny natury ludzkiej musi prowadzić do wniosku, że człowiek z natury jest zły lub ma do zła silne inklinacje wrodzone lub nabywane ${ }^{12}$. Z tego twierdzenia wynika konieczność istnienia silnego państwa, będącego „instrumentem dyscyplinującym niebezpieczną ludzką naturę poprzez jej depolityzację"13. Pogląd ten Schmitt wyraził po raz pierwszy już w 1919 r., dowodząc, że pesymistyczna antropologia jest podstawą nowożytnej i absolutystycznej wizji suwerenności sformułowanej przez Jeana Bodina ${ }^{14}$. W tymże roku w rozprawce o Niccolò Machiavellim Schmitt kreśli następujący ciąg logiczny: człowiek z natury jest zły,

11 G. Schwab, The Decision, „Revue Européenne des Sciences Sociales” 1978, nr 44, s. 6776; G.L. Negretto, El Concepto de decisionismo en Carl Schmitt. El poder negativo de la exceptión, „Revista Sociedad de la Facultad de Ciencias Sociales” 1995, nr 161, s. 66-89.

12 C. Schmitt, op. cit., s. 229-236.

13 M. Weimayr, Carl Schmitt - Sprache der Krise/Krise der Sprache, [w:] Gegen den Ausnahmezustand. Zür Kritik an Carl Schmitt, red. W. Pircher, Wien 1999, s. 53.

14 C. Schmitt, Die Idee des Einheitsstaats. Jean Bodin, [w:] idem, Die Militärzeit 1915 bis 1919. Tagebuch Februar bis Dezember 1915. Aufsätze und Materialien, Berlin 2005, s. 477, 485. 
czyli jest zdolny do „intensywnej” nienawiści, więc jest istotą polityczną — dla zachowania pokoju potrzebuje nad sobą silnej i absolutnej władzy ${ }^{15}$.

Generalizując problem, hiszpańscy badacze Hernandez Arias i José Rafael stwierdzają, że „wedle Carla Schmitta zło tkwiące w ludziach to konieczny aksjomat politycznego i państwowego absolutyzmu, na którym ufundowany jest autorytet państwa"16. Grzech pierworodny, pisze z kolei chorwacki badacz Danijel Paric, to „kamień węgielny” i podstawowy „element argumentacji dla jego teorii politycznej" o charakterze autorytarnym ${ }^{17}$. Trudno się z tymi opiniami nie zgodzić. Nie zawahamy się potwierdzić, że na założeniu o nieredukowalnym złu tkwiącym w człowieku Schmitt buduje całą swoją koncepcję państwa. Bez pesymistycznej antropologii nie ma bowiem jego teorii dyktatury, ufundowanej na koncepcji decyzjonizmu. Dlatego zaskakujący jest fakt, wskazany w literaturze przedmiotu przez Ryszarda Skarzyńskiego i Udo Tietza, że kwestia antropologiczna jest tak w samym Pojęciu polityczności, jak i w innych jego pracach prawie nieobecna i nieobjaśniona ${ }^{18}$.

Stoimy przed paradoksem: cała Schmittowska teoria polityczna opiera się na założeniu, że zło, namiętności i popędy konstytuują ludzką naturę, ale nigdy i nigdzie nie otrzymujemy z rąk Schmitta holistycznego wykładu tej problematyki. Dowiadujemy się, że człowiek jest zły, ale nie wiemy dlaczego. Z jakiej tradycji doktrynalnej pochodzi to przekonanie? Na czym jest ufundowane? Wprawdzie niektórzy badacze uważają, że wystarczy tylko przyjąć do wiadomości oczywisty fakt, że Schmittowski człowiek z natury jest zły czy też ma silne inklinacje do zła, podczas gdy źródła tego poglądu to dla wyjaśnienia jego teorii politycznej problem drugorzędny ${ }^{19}$. Dla eksplikacji teorii polityczności tak jest w istocie, jednak dla badacza myśli politycznej kwestia ta jest bardzo istotna. Dlatego na pytania o genezę pesymistycznej antropologii Schmitta musimy spróbować odpowiedzieć. Zanim jednak postaramy się takiej odpowiedzi udzielić, przeanalizujmy pokrótce międzynarodową literaturę przedmiotu i zaproponowane tam rozwiązania interesującego nas problemu.

15 C. Schmitt, Machiavelli. Zum 22. Juni 1927, [w:] idem, Staat, Großraum, Nomos. Arbeiten aus den Jahren 1916-1969, Berlin 1995, s. 102-107.

${ }^{16}$ H. Arias, J. Rafael, Donoso Cortés und Carl Schmitt. Eine Untersuchung über die Staatsund Rechtsphilosophische Bedeutung von Donoso Cortés im Werk Carl Schmitts, München 1998, s. 80 .

17 D. Paric, Anti-römischer Affekt. Carl Schmitts Interpretation der Erbsündenlehre und ihre wissenschaftsstrategische Funktion, Berlin 2002, s. 9, 33.

18 R. Skarzyński, Od chaosu do tadu. Carl Schmitt i problem tego, co polityczne, Warszawa 1992, s. 58-59; U. Tietz, „Antropologischer Ansatz politischer Theorien”. Die Freund-Feind Distinktion von Carl Schmitt, [w:] Carl Schmitt. Der Begriff des Politischen..., s. 123-124.

19 G. Gómez Orfanel, Excepcion y normalidad en el pensamiento de Carl Schmitt, Madrid 1986, s. 103-110; R. Skarzyński, op. cit., s. 58-63; D. Marcos, Acerca de los conceptos de políca y soberania en Carl Schmitt y Thomas Hobbes, „Foro Interno” 2004, nr 4, s. 55-57. 


\section{Interpretacje teologiczne}

Do 1925 r. Carl Schmitt związany był z katolicką partią Zentrum, sytuując się na jej prawym skrzydle. Był wówczas zafascynowany romańskim konserwatyzmem (J. de Maistre, L. de Bonald, J. Donoso Cortés, Ch. Maurras) i reprezentował autorytarną wersję niemieckiego katolicyzmu politycznego, o czym świadczą jego liczne prace z tego okresu ${ }^{20}$. Sytuacja zmienia się po skandalu rozwodowym i zawarciu powtórnego, cywilnego związku małżeńskiego. Schmitt jest skompromitowany w środowisku katolickim, a mając $\mathrm{z}$ drugą żoną jedynie ślub cywilny, tym samym nie jest dopuszczany do sakramentów, stając poza Kościołem katolickim. Nowa sytuacja uwidacznia się w tezie Schmitta o końcu epoki chrześcijańskiej, którą przedstawia w 1927 r. ${ }^{21}$, czyli w roku publikacji Pojęcia polityczności.

Większość badaczy (słusznie) uważa, że skoro Carl Schmitt został wychowany w środowisku ultramontańskiego katolicyzmu, to trudno sobie wyobrazić, że odszedł zeń mentalnie i intelektualnie dosłownie z dnia na dzień. Wielu znajomych Schmitta widziało w jego koncepcji konstytuującego politykę antagonizmu „my-oni” (Freund-Feind) refleks chrześcijańskiego apokaliptycznego sporu Chrystusa z Antychrystem ${ }^{22}$. Dlatego też szukając źródeł pesymistycznej antropologii Schmittowskiej, zwykle wskazuje się, że jest ona utajonym refleksem chrześcijańskiego twierdzenia o istnieniu grzechu pierworodnego. Pogląd ten znajduje swoje uzasadnienie w Pojęciu polityczności, gdzie czytamy:

Ponieważ polityczność opiera się na założeniu, że w sytuacji ostatecznej może dojść do prawdziwej walki z wrogiem, to konsekwentnie polityczne idee i argumenty nie mogą wychodzić od antropologicznego optymizmu. W przeciwnym razie wraz z odrzuceniem możliwości pojawienia się wroga zniesione zostałyby wszystkie specyficzne konsekwencje polityczności. Związek między teoriami politycznymi a teologicznym dogmatem grzechu pierworodnego, wyraźnie obecny nie tylko u takich myślicieli jak Bossuet, de Maistre, Bonald, Donoso Cortés czy Stahl, ale także u wielu innych, jest związkiem koniecznym wynikającym z politycznego powinowactwa i teologicznego myślenia. Podstawowy dogmat teologiczny o grzesznej naturze świata i człowieka [...] wprowadza w świat ludzi różnicę i dystans. Pozbawiona zastrzeżeń, optymistyczna wizja ludzkiej natury staje się po prostu niemożliwa. W świecie dobra zamieszkałym przez dobrych ludzi panuje wyłącznie pokój, bezpieczeństwo i harmonia

${ }^{20}$ Spośród najważniejszych prac „katolickich” C. Schmitta z wczesnego okresu twórczości wymienić należy: Die Sichtbarkeit der Kirche. Eine scholastische Erwägung, [w:] idem: Die Militärzeit 1915 bis 1919. Tagebuch Februar bis Dezember 1915. Aufsätze und Materialien, Berlin 2005, s. 445-452; Teologia polityczna. Cztery rozdziały poświęcone nauce o suwerenności, [w:] idem, Teologia polityczna i inne pisma, Kraków 2000, s. 33-83; Rzymski katolicyzm i polityczna forma, [w:] idem, Teologia polityczne i inne pisma..., s. 84-114. Zob. także pojedyncze artykuły na temat J. Donoso Cortésa zebrane w całość jako C. Schmitt, Donoso Cortes in gesamteuropäischer Interpretation, Köln 1950.

21 C. Schmitt, Epoka neutralizacji i apolityzacji, [w:] Rewolucja konserwatywna w Niemczech 1918-1933, red. W. Kunicki, Poznań 1999, s. 427-444.

22 A. Motschenbacher, Katechon oder Großinquisitor. Eine Studie zu Inhalt und Struktur der Politischen Theologie Carl Schmitts, Marburg 2000, s. 113. 
wszystkich ze wszystkimi. Księża i teolodzy są wówczas równie niepotrzebni jak politycy i mężowie stanu. [...] Związek między podstawowymi założeniami teologicznymi i politycznymi jest więc oczywisty ${ }^{23}$.

Pesymistyczna antropologia wydaje się mieć swoje źródło w teologii. Ale w której szkole teologicznej? Tomistycznej, augustyńskiej, protestanckiej? Aby na to ciekawe pytanie odpowiedzieć, powstała nawet niewielka monografia w języku niemieckim, autorstwa chorwackiego badacza Danijela Parica, który przyjął taką inspirację za aksjomat, o czym świadczy tytuł rozprawy: Afekt antyrzymski. Carla Schmitta interpretacja nauki o grzechu pierworodnym i jej funkcja naukowo-strategiczna (Anti-römischer Affekt. Carl Schmitts Interpretation der Erbsündenlehre und ihre wissenschaftsstrategische Funktion, Berlin 2002). Niestety, o ile w tej rozprawce problem badawczy został dobrze postawiony, o tyle nie został zadowalająco rozwiązany. Autor dowodzi, że u źródeł teorii politycznej Schmitta, szczególnie zaś Pojęcia polityczności, tkwi pesymistyczna chrześcijańska teoria antropologiczna ${ }^{24}$. Starając się ustalić o inspirację którego z nurtów chrześcijańskich chodzi, badacz analizuje doktrynę grzechu pierworodnego u ojców Kościoła (szczególnie św. Augustyna), św. Tomasza z Akwinu, Martina Lutra, Jeana Calvina, naukę Soboru w Trydencie, jansenizm czy koncepcje tradycjonalistów romańskich (J. de Maistre, L. de Bonald, J. Donoso Cortés), dochodząc do wniosku, że jest to koncepcja odległa od tomizmu i ,katolicko-humanistycznej tradycji"25, bliższa natomiast Donosowi i ,katolicyzmowi politycznemu"26. Paric postrzega Schmittowską interpretację katolickiej nauki o grzechu pierworodnym jako ,tendencyjną”, co czyni ją bliższą jansenizmowi i protestantyzmowi niż interpretacji ortodoksyjnej ${ }^{27}$.

Rozważaniom Danijela Parica postawimy jednak kilka zarzutów:

1) Jego argumentacja ma charakter ahistoryczny, gdyż za katolicką wykładnię nauki o grzechu pierworodnym badacz przyjmuje nauczanie Huguesa-Félicité-Roberta Lamennais'ego i Jacquesa Maritaina, znajdujące swoje odzwierciedlenie w nauczaniu Soboru Watykańskiego II. Zapomina, że Pojęcie polityczności napisano w 1927 r., podczas gdy Sobór Watykański II miał miejsce 40 lat później - a nie można przecież z perspektywy nauki późniejszej oceniać doktryny wcześniejszej. Gdy zaś powstawało Pojęcie polityczności, liberalne koncepcje Lamennais’ego (który w okresie liberalnym swojej twórczości minimalizował grzech pierworodny ${ }^{28}$ ) były potępione przez Rzym (w mocy pozostawała encyklika Grzegorza XVI Mirari vos, 1832). Z kolei Maritain w 1927 r. był jeszcze skrajnym neomediewalnym teokratą, potępiającym monarchistyczną Action Française

23 C. Schmitt, Pojęcie polityczności..., s. 235-236.

24 D. Paric, op. cit., s. 8-12.

25 Ibidem, s. 88-89.

26 Ibidem, s. 86.

27 Ibidem, s. 90-91.

28 F. de Lamennais, Wybór pism, Warszawa 1970, s. 548-549. 
za sekularyzm i liberalizm ${ }^{29}$. Zapowiadający nauczanie soborowe Humanizm integralny ukazał się dopiero w $1936 \mathrm{r}^{30} \mathrm{Schmitt}$ nie mógł więc przyjmować wyrażonej w tej ostatniej pracy pozycji w swojej książeczce napisanej 9 lat wcześniej. Zresztą Humanizm integralny po ukazaniu się wzbudził w środowisku katolickim oburzenie i bynajmniej nie uznawano go za ortodoksyjny.

2) $\mathrm{Z}$ punktu widzenia ortodoksji katolickiej zupełnie niezrozumiałe jest uznanie antropologii augustyńskiej za nieortodoksyjną. O ile wywiedzione z tejże antropologii tezy o łasce rzeczywiście zostały przez Kościół odrzucone (spór z protestantami i jansenistami w XVI-XVII w.), to odrzucenie nie spotkało samej koncepcji natury ludzkiej św. Augustyna. Paric wydał swoją rozprawkę w 2002 r., gdy zaraz potem augustyńską antropologię odnowił sam papież Benedykt XVI w encyklice Spe salvi (2007). O ile więc konstatacja Parica o augustyńskim źródle antropologii politycznej Schmitta jest hipotezą mającą uzasadnienie (czyli tezą), to argumentacja na rzecz jej nieortodoksyjności katolickiej jest nie do utrzymania, gdyż zasadza się na błędnych przesłankach i fałszywych twierdzeniach.

Danijel Paric ma rację, szukając źródeł Schmittowskiej nauki o człowieku w chrześcijaństwie. Nie jest to jednak teza nowatorska. W literaturze przedmiotu dawno już dominuje przekonanie, że źródłem pesymistycznej antropologii Schmitta jest chrześcijańska koncepcja grzechu pierworodnego. Spór toczy się raczej o to, z którego chrześcijańskiego nurtu ta idea wypływa. W tej kwestii można wyróżnić kilka stanowisk:

1) Większość badaczy wskazuje, dosyć ogólnikowo, że jest ona refleksem nauki katolickiej, nie wchodząc w szczegółowe rozważania, z którego kierunku teologii chrześcijańskiej ten pogląd wynika. Jest to z pewnością teza bezpieczna i trudna do zaatakowania, choć zamiast rozwiązać problem zidentyfikowania tej inspiracji, jest on pomijany (w literaturze przedmiotu pogląd ten wyrażają: G. Schwab, J. Manemann, H. Ottmann, M. Herrero López, P. Graczyk, T. Storme, S. Baume) $)^{31}$.

2) Znany badacz filozofii politycznej Hans Meier, postrzegający Schmitta jako religijnego fideistę, uważa, że jego nauka o człowieku wynika z samodzielnej egzegezy tekstu biblijnego, szczególnie zaś z fragmentu Księgi Rodzaju „inimicitias

29 J. Maritain, Primauté du Spirituel, Paris 1927.

30 J. Maritain, Humanizm integralny, Warszawa 1981.

31 G. Schwab, The Challenge of the Exception. An Introduction to the Political Ideas of Carl Schmitt between 1921 and 1936, Berlin 1970, s. 22; J. Manemann, Carl Schmitt und die Politische Theologie. Politischer Anti-Monotheismus, Münster 2002, s. 175, 182; H. Ottmann, op. cit., s. 157158; M. Herrero López, El „nomos” y lo político: La filosofia política de Carl Schmitt, Pamplona 2007, s. 222-123, 233-236; P. Graczyk, Katolicyzm polityczny, „Kronos” 2008, nr 3, s. 128-129; T. Storme, Carl Schmitt et le marcionisme. L'impossibilité théologico-politique d'un oecuménisme judéo-chrétien?, Paris 2008, s. 41-46; S. Baume, Carl Schmitt, penseur de l'Etat, Paris 2008, s. $165-166$. 
ponam inter te et mulierem et semen tuum" $(\mathrm{Rz} 3,15)^{32}$. Badacz ten twierdzi, że cała Schmittowska teoria polityczności to zsekularyzowana koncepcja walki ortodoksji z herezją, gdzie „my” to ci ortodoksyjni, a „oni” to heretycy ${ }^{33}$.

3) Kilku badaczy przyjmuje pogląd podobny do Parica i sądzi, że Schmittowska antropologia ma swoje źródło w nauce augustyńskiej (M. Weimayr) ${ }^{34}$, ewentualnie augustyńskiej z trudnymi do ostatecznego zidentyfikowania elementami fideizmu, być może zaczerpniętymi od Blaise'a Pascala lub Martina Lutra $(\mathrm{T} \text {. Storme })^{35}$, co ustawia tę koncepcję na granicy ortodoksji, ale jej nie przekracza. Dodajmy, że augustynizm, będąc najbardziej pesymistycznym w kwestii ludzkiej natury w całym katolicyzmie, mieści się jeszcze w granicach ortodoksji ${ }^{36}$.

4) W literaturze przedmiotu można jednak spotkać również taki pogląd, że jest to augustyńska koncepcja natury tak skrajna, że w istocie już wychodząca poza katolicyzm, gdyż luterańska, a więc oparta o zasadę predestynacji, z której Luter wyprowadzał swoją ideę Obrigkeitstaatu ${ }^{37}$. Wedle tej interpretacji Schmitt głosi niezwykle radykalnie pesymistyczną wizję człowieczeństwa, gdzie zanika ludzka wolna wola, niemogąca czynić nigdy i nigdzie sprawiedliwie z powodu totalnej destrukcji naszej natury przez dziedziczny grzech pierworodny (G. Maschke, K.E. Lönne, H. Arias, J. Rafael) ${ }^{38}$. Wariacją tej tezy jest oryginalna myśl Manfreda Dahlheimera, że mamy tutaj do czynienia z nauką o grzechu pierworodnym Lutra, skutkującą „,chrześcijańskim makiawelizmem”39.

Interpretacja pierwsza jest nazbyt ogólnikowa, aby z nią dyskutować. Druga jest osobistą intuicją Heinricha Meiera, wynikłą z ogólnego kontekstu jego odczytania Schmitta, i trudno polemizować z hipotezą, na którą sam prezentujący ją badacz nie przedstawił dowodów. Interpretacje trzecia i czwarta stoją zgodnie na stanowisku, że źródłem Schmittowskiej koncepcji natury ludzkiej jest teologia św. Augustyna, różniąc się w interpretacji, czy wizja ta jeszcze mieści się

${ }^{32}$ H. Meier, Die Lehre Carl Schmitts. Vier Kapitel zur Unterscheidung Politischer Theologie und Politischer Philosophie, Stuttgart 2004, s. 30-31.

${ }^{33}$ H. Meier, Carl Schmitt, Leo Strauss und „Der Begriff des Politischen”. Zu einem Dialog unter Abwesenden, Stuttgart 1998, s. 54-56, 86-87; idem, Die Lehre Carl..., s. 78-79.

34 M. Weimayr, op. cit., s. 65.

35 T. Storme, op. cit., s. 45, przypis 2.

36 Zob. E. Gilson, Wprowadzenie do nauki św. Augustyna, Warszawa 1953, s. 189-220; A. Villalmonte, El problema del mal y el pecado original en San Agustín, „Naturaleza y Gracia” 1991, nr 3, s. 235-263.

37 P. Mesnard, L'Essor de la Philosophie Politique au XVI siècle, Paris 1952, s. 230-234; M. Scattola, Teologia polityczna, Warszawa 2011, s. 87-89.

38 G. Maschke, La Reprezentazione Cattolica. Carl Schmitts Politische Theologie mi Bllick auf italienische Beiträge, „Der Staat” 1989, nr 28, s. 558-559; K.E. Lönne, Carl Schmitt und der Katholizismus der Weimarer Republik, [w:] Die eigentlich katholische Verschärfung... Konfession, Theologie und Politik im Werk Carl Schmitts, red. B. Wacker, München 1994, s. 25; H. Arias, J. Rafael, op. cit., s. 62, 79-80.

39 M. Dahlheimer, Carl Schmitt und der deutsche Katholizismus, 1886-1936, Paderborn 1998, s. 332, przypis 1414. 
w ortodoksji katolickiej czy też nie. Jeśli antropologia polityczna Schmitta posiada genezę teologiczną, to bez wątpienia jest nią teologia św. Augustyna. Ale z interpretacją nr 4, mówiącą o wykroczeniu poza nauczanie katolickie, wejdziemy w polemikę z dwóch powodów:

a) Martin Luter głosił swoje skrajnie pesymistyczne tezy antropologiczne w pewnym kontekście: wszyscy ludzie mają zepsutą przez grzech pierworodny naturę, żaden człowiek nie może więc dokonać swojego samozbawienia dzięki wierze i uczynkom. Dlatego reformatorzy wprowadzali w tym miejscu łaskę udzieloną przez Boga, dzięki której (nieliczni) predestynowani do zbawienia mogą czynić sprawiedliwie (sola gratia) ${ }^{40}$. Skoro jednak Schmitt o łasce i predestynacji nic nigdzie nie pisze, musielibyśmy uznać, że jego koncepcja jest bardziej radykalna niż samego Lutra, a co za tym idzie Schmitt byłby chrześcijaninem głoszącym, że zbawienie jest... niemożliwe.

b) Interpretację pozaortodoksyjną możemy odrzucić nie tylko z powodu przyzwoitej formacji katolickiej wyniesionej przez Schmitta z domu, lecz także dlatego, że 10 lat przed publikacją Pojęcia polityczności, w szkicu Widzialność Kościoła (Die Sichtbarkeit der Kirche. Eine scholastische Erwägung, 1917), znajdujemy jasną i niepozostawiającą wątpliwości ortodoksyjną wykładnię problemu grzechu: „,́wiat jest dobry i to, co jest w nim złe, to skutek ludzkich grzechów"41. Ze zdania tego wynika, że zło powstało z ludzkich grzechów (teodycea). To zaś znaczy, że ludzie, aby móc popełniać zło i popsuć pierwotnie dobry świat, muszą mieć wolną wolę, a więc mogą czynić zarówno sprawiedliwie, jak i niesprawiedliwie bez Bożej Łaski. Luter nigdy nie podpisałby się pod taką ,,pelagiańską” (w jego oczach) formułą, z którą zawzięcie walczył przy okazji polemik z Erazmem z Rotterdamu ${ }^{42}$. Poza tym w pracach Schmitta z 1922 i 1923 r. natrafiamy na fragmenty, z których wynika, że znał on zarówno Trydenckie dokumenty na temat łaski i usprawiedliwienia ${ }^{43}$, jak i był świadomy tego, że skrajnie pesymistyczna antropologia Donosa wykracza poza katolicką ortodoksję. Schmitt pisze bowiem:

40 M. Luter, Von den Guten Werken, [w:] Quellentexte theologischer Ethik. Von der Altern bis zur Gegenwart, red. S. Grotefeld, Stuttgart 2006, s. 111-113; idem, De Servo Arbitrio [O niewolnej woli], Świętochłowice 2002, s. 335 n.; idem, Grzech pierworodny oznacza zupetne zepsucie człowieka, [w:] E. Piotrowski, T. Węcłowski, Praeceptores. Teologia i teologowie języka niemieckiego, Poznań 2005, s. 82-83.

41 C. Schmitt, Die Sichtbarkeit der Kirche. Eine scholastische Erwägung, [w:] idem, Die Militärzeit 1915 bis 1919. Tagebuch Februar bis Dezember 1915. Aufsätze und Materialien, Berlin 2005, s. 445 / 445-452.

${ }^{42}$ M. Luter, De Servo Arbitrio... W literaturze zob. np. A. Ściegienny, Spór Erazma z Lutrem, [w:] Antynomie wolności. Z dziejów filozofii wolności, red. M. Drużkowski, K. Sokół, Warszawa 1966, s. 185-204; Ch. Boyer: Luther. Sa doctrine, Rome 1970, s. 82-112; F. de Michelis Pintacuda, Tra Erasmo e Lutero, Roma 2007, s. 39-114.

43 C. Schmitt, Teologia polityczna..., s. 76; idem, Katolicyzm rzymski..., s. 88, 91. 
w ujęciu Cortésa dogmat ten [o grzechu pierworodnym - A.W.] przyjął radykalną formę i przerodził się w pogląd, że ludzka natura została całkowicie skażona i dlatego człowiek jest niezdolny do dobra. Cortés odbiegał więc od przyjętej w dogmacie trydenckim wykładni grzechu pierworodnego [wyr. - A.W.], zgodnie z którą - inaczej niż w naukach Lutra - ludzka natura nie została całkowicie skażona, lecz jest jedynie zmącona przez grzech pierworodny, doznała pewnego uszczerbku, ale w dalszym ciągu człowiek z natury swej zdolny jest do czynienia dobra. $Z$ tego właśnie powodu ojciec Gaduel miał rację [wyr. - A.W.], krytykując Donoso Cortésa za przesadny pesymizm wobec ludzkiej natury i za określenie jej mianem podłej, co było dlań nie do przyjęcia z powodów dogmatycznych ${ }^{44}$.

Stoimy na stanowisku, że przy skąpym materiale źródłowym celowe wydaje się poszukiwanie rozwiązań prostszych niż pośrednictwo Lutra, na które brak nawet cienia dowodu, na uzasadnienie którego nie można przytoczyć ani jednego cytatu źródłowego. Schmitt nigdy nie zachwycał się ojcem reformacji i cytował go rzadko, choć znał jego polemiki z Erazmem z Rotterdamu ${ }^{45}$. Uważamy, że prostszym wyjaśnieniem byłoby uznanie, że Luter i Schmitt korzystali, w kwestii antropologii, z tego samego źródła teologicznego, a mianowicie z pism św. Augustyna. Ewentualnie Schmitt korzystał z prac zwolenników św. Augustyna wiernie odtwarzających jego myśl teologiczną w tej kwestii.

W literaturze na temat reformacji już dawno zwrócono uwagę, że Martin Luter, interpretując św. Augustyna, mocno podkreślał zepsucie ludzkiej natury, w wyniku czego zanegował w ogóle istnienie wolnej woli na korzyść predestyna$\mathrm{cji}^{46}$. Tak radykalny pogląd nie był formułowany przez biskupa z Hippony ${ }^{47}$. Natomiast w przytaczanym wcześniej cytacie z tekstu Widzialność Kościoła Schmitt zinterpretował św. Augustyna poprawnie, wskazując, że to ludzki grzech uczynił zło, czyli Adam posiadał wolną wolę, tak jak i my ją posiadamy, choć została ona przez grzech zepsuta i ma naturalną predylekcję do grzechu. Schmitt poczynił wówczas ważne zastrzeżenie - które potwierdza naszą interpretację — a mianowicie, że skutki grzechu można cofnąć dzięki „uświęceniu” (die Ehe) za pomocą sakramentów, którymi szafuje Kościół katolicki ${ }^{48}$. Nie jest to pogląd protestanc-

44 C. Schmitt, Teologia polityczna..., s. 76. Chodzi o serię artykułów ks. J.P Gaduela na łamach „L'ami de réligion” z 1852 r., wielce krytycznych wobec myśli teologicznej J. Donosa Cortésa.

45 C. Schmitt, Tagebücher. Oktober 1912 bis Februar 1915, Berlin 2005, s. 294.

$46 \mathrm{Na}$ temat antropologii luterańskiej zob. np. R. Hermann, Luthers Theologie, Göttingen 1967, s. 164-168; H.J. MacSorley, Luthers Lehre vom unfreien Wille nach seine Hauptschrift „,De Servo Arbitrio” im Lichte der biblischen und kirchlichen Tradition, München 1967, s. 64-109; B. Lohse: Evangelium in der Geschichte, t. 1, Göttingen 1988, s. 11-30; T. Szczech, Państwo i prawo w doktrynie św. Augustyna, Marcina Lutra i Jana Kalwina, Łódź 2006, s. 17-18, 34-62.

47 O problemie wolnej woli u „oryginalnego” św. Augustyna zob. E. Gilson, op. cit., s. 202220; P. Koslowski, Der freie und der unfreie Wille und der Ursprung des Bösen, [w:] Der freie und unfreie Wille. Philosophische und theologische Perspektiven, red. F. Hermani, München 2004, s. $131-148$.

48 C. Schmitt, Die Sichtbarkeit der Kirche..., s. 451. 
ki. Reformatorzy religijni z XVI stulecia podważali przecież rolę sakramentów oraz ich szafarza w postaci Kościoła katolickiego, utrzymując, że nie mają one znaczenia, gdyż nasze zbawienie determinowane jest wyłącznie przez udzielaną (lub nie) przez Boga łaskę ${ }^{49}$. To w tym kontekście pojawia się słynne kalwińskie określenie łaski jako „kaprysu” Boga (le bon plaisir ${ }^{50}$.

Jeśli więc teza o religijnych źródłach Schmittowskiej nauki o człowieku jest słuszna, to teologicznym źródłem antropologii politycznej Carla Schmitta jest św. Augustyn, interpretowany zgodnie z Magisterium Kościoła katolickiego. Tylko czy samo stwierdzenie, że jego antropologia polityczna ma genezę wyłącznie w chrześcijańskiej teologii rzeczywiście jest aksjomatem, czyli twierdzeniem niewymagającym dowodu?

\section{Interpretacje pozateologiczne}

Opisana powyżej interpretacja przyjmuje jako aksjomat, że pesymistyczna antropologia Schmittowska koniecznie musi mieć podglebie teologiczne i że jest to jedyne jej źródło. Taką tezę głosi wprost tak skrytykowany przez nas Danijel Paric, utrzymujący, że każda doktryna polityczna ma u swoich źródeł twierdzenia religijne i dzieje się tak nawet we współczesnej i głęboko zsekularyzowanej epoce, ponieważ politologia nie jest w stanie uciec od swoich teologicznych źródeł ${ }^{51}$. To założenie może jednak być błędne. Jeśli spojrzymy na biografie wielu myślicieli politycznych, spostrzeżemy, że ich ocena natury ludzkiej wydaje się pochodną otaczającej ich sytuacji politycznej, lecz także osobistej.

Klasycy pesymizmu antropologicznego żyli w epoce najazdów i upadku imperium, w którym się urodzili (św. Augustyn) oraz krwawych wojen domowych (N. Machiavelli, T. Hobbes). W literaturze pisano wielokrotnie, że teoria państwa i polityki Schmitta ma u swojego źródła krach niemieckich marzeń o imperium, czyli porażkę wojenną z 1918 r. (S. Baume) $)^{52}$. Bardzo liczne grono badaczy twierdzi, że była ona wynikiem trwogi przed bolszewikami, którzy wygrali wojnę domową w Rosji i próbowali wzniecić rewolucję również w Niemczech (J.W. Bendersky, M. Staglieno, P. Jiménez, G. Balakrishnan) ${ }^{53}$. Wedle podobnej interpretacji miałaby być wynikiem osobistej empirycznej obserwacji zbrodni do-

49 M. Luter, Büchlein von der babylonischen Gefängnis der Kirche, [w:] idem, Die reformatischen Schriften, t. 2, Darmstadt 1847, s. 37-162. W literaturze zob. klasyczne opracowanie J.A. Möhler, Symbolika, czyli wykład dogmatycznych niezgodności pomiędzy katolikami i protestantami podtug ich publicznych wyznań wiary, Warszawa 1871, s. 201-255.

50 J. Calvin, Traité de la justification, Amsterdam 1693, s. 361.

51 D. Paric, op. cit., s. 8.

52 S. Baume, op. cit., s. 11.

53 J.W. Bendersky, Carl Schmitt. Theorist for the Reich, Princeton 1983, s. 21-22; M. Staglieno, Spengler, Thomas Mann, Carl Schmitt, [w:] Sul destino, red. S. Zecchi, Bologna 1991, s. 296; P. Jiménez, La reacción contra la historia. Donoso Cortés y Carl Schmitt, [w:] Nuevas tendencias his- 
konanych przez rewolucjonistów z jednej strony, ale też z drugiej — kontrrewolucyjne Freikorpsy w 1919 r. w Bawarii oraz podczas licznych rewolt i zamachów mających miejsce w Republice Weimarskiej w latach 1919-1923 (H. Quaritsch, P. Noack $)^{54}$.

Od siebie dodamy także hipotezę, że źródło pesymizmu antropologicznego Carla Schmitta może być znacznie bardziej banalne i może stanowić je jego własne doświadczenie życiowe. Niedawne przejścia rozwodowe (1924-1925) mogły zachęcić go do uznania, że ludzie (czytaj: była żona) to istoty z natury złe i perfidne, co znalazło swój wyraz w pismach politycznych z 1927 r. Na pogląd ten nie znajdujemy w tekstach źródłowych żadnego dowodu (kto napisałby coś takiego?), ale przecież nie można go wykluczyć. Skoro najazdy i wojny domowe wytwarzają u filozofów pesymistyczną wizję człowieka, to dlaczego takiego skutku nie mógłby wywołać skandal rozwodowy, publiczna kompromitacja i usunięcie poza obręb Kościoła?

Carl Schmitt nic nigdzie nie napisał o swoich osobistych i mających źródło w bieżących wydarzeniach politycznych źródłach pesymistycznej antropologii. Jest jednak oczywiste, że Schmittowska teoria kondycji ludzkiej nie powinna być alienowana od jego sytuacji osobistej i politycznej, od przegranej wojny, upadku cesarstwa i zagrożenia komunistycznego.

Dlatego nie wszyscy badacze podzielają pogląd, że Schmittowska nauka o człowieku ma źródła religijne. Wielu badaczy uważa, że jest ona pokłosiem pogłębionej lektury Hobbesowskiego Lewiatana (1651), która zaowocowała klasyczną rozprawą Schmitta Lewiatan w teorii państwa Thomasa Hobbesa $(1938)^{55}$. W tej interpretacji Schmittowska koncepcja natury ludzkiej miałaby źródła laickie i filozoficzne (H. Rumpf, J.M. McCormick, R. Mehring, L. Strauss) ${ }^{56}$. Carl Schmitt daje nam pełne prawo do takiej interpretacji, gdyż w Pojęciu polityczności czytamy:

Hobbes, jeden z największych prawdziwie systemowych myślicieli politycznych, słusznie zauważył, że to właśnie przekonanie ludzi o tym, iż reprezentują prawdę, dobro i sprawiedliwość, rodzi najgorsze konflikty, bellum wszystkich ze wszystkimi. Stąd też naszkicowaną przez niego

toriográficas e historia local en España, red. M.A. Ruiz Carnicer, C. Frias Corredor, Zaragoza 2001, s. 407-408; G. Balakrishnan, op. cit., s. 52.

54 H. Quaritsch, Positionen und Begriffe Carl Schmitts, Berlin 1995, s. 39-40; P. Noack, Carl Schmitt. Eine Biographie, Berlin 1996, s. 53-54.

55 C. Schmitt, Lewiatan w teorii państwa Thomasa Hobbesa, Warszawa 2008.

56 H. Rumpf, Carl Schmitt und Thomas Hobbes. Ideelle Beziehungen und aktuelle Bedeutung mit einer Abhandlung über die Frühschriften Carl Schmitts, Berlin 1972, s. 76-78; J.M. McCormick, Carl Schmitt's Critique of Liberalism. Against Politics as Technology, Cambridge 1999, s. 252 253; R. Mehring, Esoterische „Hinweise”? Marginalien zum Feindgebriff und „antropologischen Glaubensbekenntnis", [w:] Carl Schmitt. Der Begriff des Politischen..., s. 201-202; L. Strauss, Uwagi do „Pojęcia polityczności” Carla Schmitta, „Kronos” 2008, nr 3, s. 65-68; J.P. McCormick, Educable or Sinflul..., s. 179, 193. 
„pesymistyczną” wizję ludzkiej natury uznać należy nie za koszmarny wymysł chorej wyobraźni [...], ale za najważniejsze założenie specyficznie politycznego sposobu myślenia ${ }^{57}$.

Dodatkowo z opublikowanych dopiero w 2001 r. inedita Carla Schmitta z 1919 r. dowiadujemy się, że Hobbes słusznie twierdził, że w naturze ludzkiej i stosunkach politycznych dominują negatywne instynkty ${ }^{58}$. Pisząc o genezie nauki o człowieku Schmitta, nie sposób więc pominąć Thomasa Hobbesa.

\section{Interpretacja autorska}

Z przedstawionego wyżej wywodu klaruje się nasze stanowisko w kwestii genezy i źródeł pesymistycznej antropologii politycznej Carla Schmitta. Składa się na nią kilka tradycji, z których za potwierdzone w literze źródłowej należy uznać interpretowaną po katolicku teologię św. Augustyna oraz filozofię państwa Thomasa Hobbesa. Z kolei z tradycji badawczej poświęconej Schmittowi wynika prawdopodobny charakter bieżących czynników politycznych z lat 1918-1923. Nie można także wykluczyć czynnika personalnego.

Chcemy mocno podkreślić ten wieloźródłowy charakter powstania Schmittowskiej koncepcji natury ludzkiej. $Z$ niezrozumiałych dla nas powodów praktycznie wszyscy badacze omawianej przez nas problematyki — wyjąwszy jednego jedynego amerykańskiego badacza Paula E. Gottfrieda ${ }^{59}$ - uznali, że antropologia ta musi mieć swoje źródło w jednym czynniku, w jednej tradycji teologicznej albo filozoficznej. Innymi słowy: albo św. Augustyn (ortodoksyjnie lub heterodoksyjnie pojmowany), albo Hobbes. Ewentualnie tradycja ta mogła ulec jeszcze wzmocnieniu z powodu otaczającej Schmitta rzeczywistości politycznej. Uważamy, że jest to - wielokrotnie opisywany w literaturze metodologicznej nauk społecznych, już od czasów Davida Hume’a — tzw. błąd monocausalności, prowadzący do symplifikacji. Stoimy na stanowisku, że pesymizm antropologiczny Schmitta ma kilka źródeł równocześnie, ponieważ niemiecki prawnik czerpał swoje inspiracje zarówno z dzieł rozmaitych autorów — od św. Augustyna po Thomasa Hobbesa - jak i obserwacji okresu rewolucji i anarchii znamionujących jego epokę.

Błąd monocausalności jest dla nas niezrozumiały nie tylko $\mathrm{z}$ tego powodu, że jest to wykroczenie przeciwko abecadłu każdego badacza myśli politycznej (politologa) lub doktryn polityczno-prawnych (prawnika), lecz także dlatego, że na heterogeniczne źródło swojej antropologii politycznej wprost wskazuje sam Schmitt. W Pojęciu polityczności czytamy, że „prawdziwe teorie polityczne

57 C. Schmitt, Pojęcie polityczności..., s. 236.

58 C. Schmitt, Thomas Hobbes / Baruch Spinoza, [w:] idem, Schmittiana. Beiträge zu Leben und Werk Carl Schmitts, t. 7, Berlin 2001, s. 10-11.

59 P.E. Gottfried, Carl Schmitt. Politics and Theory, New York 1990, s. 64-66. 
muszą zakładać, iż człowiek z natury jest zły lub przynajmniej, że jest istotą problematyczną, niespokojną i niebezpieczną"60. Następnie Schmitt wymienia tych klasyków, których postrzega jako piszących w tej tradycji. Są to: Niccolò Machiavelli, Thomas Hobbes, Jacques Bossuet, Johann G. Fichte, Joseph de Maistre, Juan Donoso Cortés, Hippolyte Taine i Georg W.F. Hegel ${ }^{61}$. Mamy tutaj wymienionych jednym tchem myślicieli klasycznych dla romańskiego autorytarnego katolicyzmu politycznego, opierających się na św. Augustynie (J. Bossuet, J. de Maistre, J. Donoso Cortés), filozofów protestanckich hołdujących rozmaitym kierunkom filozoficznym (T. Hobbes, J.G. Fichte, G.W.F. Hegel, H. Taine) i antychrześcijańskich (N. Machiavelli). W innym miejscu tej samej rozprawki wymienieni zostają w tym kontekście de Maistre, Bonald, Donoso i dodatkowo konserwatywny ewangelik Friedrich J. von Stahl ${ }^{62}$.

Podobne wyliczenie istotnych pisarzy rozumiejących naturę ludzką, a więc również naturę polityki oraz wynikłych z nich konieczności istnienia państwa autorytarnego, znajdujemy także w Dyktaturze (Die Diktatur. Von den Anfängen des modernen Souveränitätsgedankens bis zum proletarischen Klassenkampf, 1921), gdzie mamy wymienionego - poza wcześniej wspomnianymi Hobbesem, Bossuetem, de Maistrem i Stahlem - Martina Lutra ${ }^{63}$. Z kolei w Teologii politycznej (1922) Schmitt wylicza w tym samym kontekście raz jeszcze myślicieli kontrrewolucyjnych: de Maistre'a, Bonalda i Donosa ${ }^{64}$.

Dodatkowo expressis verbis w Pojęciu polityczności czytamy, że myśl chrześcijan oraz Hobbesa stanowią dwa niezależne źródła refleksji Schmitta na temat zjawiska polityczności, gdyż „koncepcje polityczne wymienionych wcześniej myślicieli” oraz „ich sposób myślenia o polityce” możemy „uważać za przejaw realizmu"65.

Z wyliczeń tych wyprowadzamy dwa końcowe wnioski:

1) Rozpowszechniona $w$ literaturze przedmiotu interpretacja monocausalna została przez nas aż pięć razy zanegowana za pomocą tekstów źródłowych, i to powszechnie dostępnych, uchodzących za najbardziej klasyczne pisma Schmitta. Teoria monocausalna genezy Schmittowskiego pesymizmu antropologicznego została odparta.

2) We wszystkich czterech wyliczeniach autorów realistycznie patrzących na zjawiska polityczne brakuje św. Augustyna. To pominięcie musi zaskakiwać i dziwić, ale też zmusza nas do modyfikacji ugruntowanej w literaturze przedmiotu - a przyjmowanej aż dotąd także przez nas — tezy, że pesymistyczna antropologia Schmitta pochodzi bezpośrednio z lektury pism tego ojca Kościoła. W dziełach Schmitta

${ }^{60}$ C. Schmitt, Pojęcie polityczności..., s. 232.

61 Ibidem.

62 Ibidem, s. 235.

63 C. Schmitt, Die Diktatur. Von den Anfängen des modernen Souveränitätsgedankens bis zum proletarischen Klassenkampf, Berlin 2006, s. 40.

64 C. Schmitt, Teologia polityczna..., s. 76-77.

65 C. Schmitt, Pojęcie polityczności..., s. 236. 
sprzed powstania Pojęcia polityczności większy fragment na jego temat znajdujemy tylko raz, w prywatnym zapisku świadczącym, że prawnik pilnie studiuje jego teodyceę $^{66}$. Z tego samego źródła wiemy, że w tym czasie studiował teologów i filozofów mediewalnych piszących w tradycji augustyńskiej: Anzelma z Cantenbury i mistyków z kierunku tzw. devotio moderna (Angelus Silesius, Mistrz Eckart, Jan van Ruusbroec) ${ }^{67}$. Przede wszystkim jednak Schmitt jest Augustynistą za pośrednictwem kilku wymienionych wcześniej myślicieli, na których myśli politycznej św. Augustyn odcisnął znaczące piętno: Lutra (a za jego pośrednictwem F. J. von Stahla) oraz katolików: Bossueta, de Maistre'a i Donosa68.

\section{Bibliografia}

Altmann R., Analytiker des Interims. Wer war Carl Schmitt, was ist von ihm geblieben?, [w:] Carl Schmitt und die Liberalismuskritik, red. H. Lietzmann, K. Hansen, Opladen 1988.

Arias H., Rafael J., Donoso Cortés und Carl Schmitt. Eine Untersuchung über die Staats- und Rechtsphilosophische Bedeutung von Donoso Cortés im Werk Carl Schmitts, München 1998.

Balakrishnan G., L'ennemi. Un portrait intellectuel de Carl Schmitt, Paris 2006.

Baume S., Carl Schmitt, penseur de l'Etat, Paris 2008.

Baumert R., Carl Schmitt contre le parlementarisme weimarien. Quatorze ans de rhétorique réactionnaire, „Revue française de Science Politique” 2008, nr 58.

Bendersky J.W., Carl Schmitt. Theorist for the Reich, Princeton 1983.

Boyer Ch., Luther. Sa doctrine, Rome 1970.

Brunkhorst H., Der Leviathan und die Intellektuellen. Carl Schmitts theologisches Missverständnis des Politischen, [w:] Les Intellectuels et l'Etat sous la République de Weimar, red. M. Gangl, H. Roussel, Paris 1993.

Calvin J., Traité de la justification, Amsterdam 1693.

Caturelli A., Donoso Cortés. Ensayo sobre su filosofia de la historia, Cordoba 1958.

Chaix Ruy J., Donoso Cortés. Théologien de l'Histoire et prophète, Paris 1956.

Dahlheimer M., Carl Schmitt und der deutsche Katholizismus, 1886-1936, Paderborn 1998.

Dotti J.E., Estado, Representación, Guerra. Algunas consideraciones sobre la concepción Hobbesiano-Schmittiana de lo político, „Revista de Ciencias Sociales” 2012, nr specjalny: Carl Schmitt: Análisis Crítico.

Froidefont M., Théologie de Joseph de Maistre, Paris 2010.

Garcia-Pelayo M., Idea de la política, Caracas 1968.

Gilson E., Wprowadzenie do nauki św. Augustyna, Warszawa 1953.

66 C. Schmitt, Tagebücher..., s. 295.

67 Ibidem, s. 34, 141-142, 188, 192-193, 200, 359.

68 Wpływ św. Augustyna na tych myślicieli był wielokrotnie sygnalizowany w literaturze. $\mathrm{O}$ wpływie na M. Lutra już pisaliśmy (zob. przypis 46). O podobnym wpływie na myślicieli francuskich zob. M. Froidefont, Théologie de Joseph de Maistre, Paris 2010, s. 125-142; G. Minois, Bossuet. Entre Dieu et le Soleil, Paris 2003, s. 361-365. Istnieje pokaźna literatura dotycząca tegoż wpływu na J. Donoso Cortésa; zob. np. D. Sevilla, El impacto de San Agustín en Donoso, [w:] La Ciudad de Dios, t. 2, Escorial 1955, s. 621-645; J. Chaix Ruy, Donoso Cortés. Théologien de l'Histoire et prophète, Paris 1956, s. 170-171; A. Caturelli, Donoso Cortés. Ensayo sobre su filosofia de la historia, Cordoba 1958, s. 27-36, 47-57. 
Gómez Orfanel G., Excepcion y normalidad en el pensamiento de Carl Schmitt, Madrid 1986.

Gottfried P.E., Carl Schmitt. Politics and Theory, New York 1990.

Graczyk P., Katolicyzm polityczny, „Kronos” 2008, nr 3.

Gralher M., Antinomisches Denken und dilemmatische Kontrastdialektik. Warum Carl Schmitt kein Liberaler sein konnte, [w:] Carl Schmitt und die Liberalismuskritik, red. H. Lietzmann, K. Hansen, Opladen 1988.

Hansen K., Feindberührungen nur versöhnlichen Ausgang. Carl Schmitt und der Liberalismus, [w:] Carl Schmitt und die Liberalismuskritik, red. H. Lietzmann, K. Hansen, Opladen 1988.

Herrera C., Carl Schmitt y el marxismo. Puntos de encuentro y de ruptura en la noción de realismo político, „Res Publica” 1998, nr 2.

Hermann R., Luthers Theologie, Göttingen 1967.

Herrero López M., El „nomos” y lo político: La filosofia politica de Carl Schmitt, Pamplona 2007. Jiménez P., La reacción contra la historia. Donoso Cortés y Carl Schmitt, [w:] Nuevas tendencias historiográficas é historia local en España, red. M.A. Ruiz Carnicer, C. Frias Corredor, Zaragoza 2001.

Koslowski P., Der freie und der unfreie Wille und der Ursprung des Bösen, [w:] Der freie und unfreie Wille. Philosophische und theologische Perspektiven, red. F. Hermani, München 2004.

Lamennais F. de, Wybór pism, Warszawa 1970.

Lohse B., Evangelium in der Geschichte, t. 1, Göttingen 1988.

Lönne K.E., Carl Schmitt und der Katholizismus der Weimarer Republik, [w:] Die eigentlich katholische Verschärfung... Konfession, Theologie und Politik im Werk Carl Schmitts, red. B. Wacker, München 1994.

Luter M., Büchlein von der babylonischen Gefängnis der Kirche, [w:] idem, Die reformatischen Schriften, t. 2, Darmstadt 1847.

Luter M., De Servo Arbitrio [O niewolnej woli], Świętochłowice 2002.

Luter M., Grzech pierworodny oznacza zupetne zepsucie człowieka, [w:] E. Piotrowski, T. Węcłowski: Praeceptores. Teologia i teologowie języka niemieckiego, Poznań 2005.

Luter M., Von den Guten Werken, [w:] Quellentexte theologischer Ethik. Von der Altern bis zur Gegenwart, red. S. Grotefeld, Stuttgart 2006.

MacSorley H.J., Luthers Lehre vom unfreien Wille nach seine Hauptschrift „,De Servo Arbitrio” im Lichte der biblischen und kirchlichen Tradition, München 1967.

Manemann J., Carl Schmitt und die Politische Theologie. Politischer Anti-Monotheismus, Münster 2002.

Marcos D., Acerca de los conceptos de polica y soberanía en Carl Schmitt y Thomas Hobbes, „Foro Interno" 2004, $\mathrm{nr} 4$.

Maritain J., Humanizm integralny, Warszawa 1981.

Maritain J., Primauté du Spirituel, Paris 1927.

Maschke G., Drei Motive im Anti-Liberalismus Carl Schmitts, [w:] Carl Schmitt und die Liberalismuskritik, red. H. Lietzmann, K. Hansen, Opladen 1988.

Maschke G., La Reprezentazione Cattolica. Carl Schmitts Politische Theologie mi Bllick auf italienische Beiträge, „Der Staat” 1989, nr 28.

McCormick J.P., Educable or Sinflul Evil? Revisting the Moral Status of the Political in the SchmittStrauss Exchange, [w:] The Problem of Political Theology, red. A. Górnisiewicz, P. Armada, K.C. Matuszek, Kraków 2012.

Mehring R., Esoterische „Hinweise”? Marginalien zum Feindgebriff und „, antropologischen Glaubensbekenntnis", [w:] Carl Schmitt. Der Begriff des Politischen. Ein kooperativer Kommentar, red. idem, Berlin 2003.

Meier H., Carl Schmitt, Leo Strauss und „Der Begriff des Politischen”. Zu einem Dialog unter Abwesenden, Stuttgart 1998.

Studia nad Autorytaryzmem i Totalitaryzmem 39, nr 1, 2017

(C) for this edition by CNS 
Meier H., Die Lehre Carl Schmitts. Vier Kapitel zur Unterscheidung Politischer Theologie und Politischer Philosophie, Stuttgart 2004.

Mesnard P., L'Essor de la Philosophie Politique au XVI siècle, Paris 1952.

Michelis Pintacuda F. de, Tra Erasmo e Lutero, Roma 2007.

Minois G., Bossuet. Entre Dieu et le Soleil, Paris 2003.

Möhler J.A., Symbolika, czyli wykład dogmatycznych niezgodności pomiędzy katolikami i protestantami podtug ich publicznych wyznań wiary, Warszawa 1871.

Molnar T., The Decline of the Intelectual, Cleveland 1961.

Motschenbacher A., Katechon oder Großinquisitor. Eine Studie zu Inhalt und Struktur der Politischen Theologie Carl Schmitts, Marburg 2000.

Negretto G.L., El Concepto de decisionismo en Carl Schmitt. El poder negativo de la exceptión, „Revista Sociedad de la Facultad de Ciencias Sociales” 1995, nr 161.

Nicoletti M., Transcendenza é potere. La teologia política di Carl Schmitt, Brescia 1990.

Noack P., Carl Schmitt. Eine Biographie, Berlin 1996.

Ottmann H., „,Das Zeitalter der Neutralisierungen und Entpolitisierungen”. Carl Schmitts Theorie der Neuzeit, [w:] Carl Schmitt. Der Begriff des Politischen. Ein kooperativer Kommentar, red. R. Mehring, Berlin 2003.

Paric D., Anti-römischer Affekt. Carl Schmitts Interpretation der Erbsündenlehre und ihre wissenschaftsstrategische Funktion, Berlin 2002.

Quaritsch H., Positionen und Begriffe Carl Schmitts, Berlin 1995.

Rumpf H., Carl Schmitt und Thomas Hobbes. Ideelle Beziehungen und aktuelle Bedeutung mit einer Abhandlung über die Frühschriften Carl Schmitts, Berlin 1972.

Scattola M., Teologia polityczna, Warszawa 2011.

Schmitt C., Die Diktatur. Von den Anfängen des modernen Souveränitätsgedankens bis zum proletarischen Klassenkampf, Berlin 2006.

Schmitt C., Die Idee des Einheitsstaats. Jean Bodin, [w:] idem, Die Militärzeit 1915 bis 1919. Tagebuch Februar bis Dezember 1915. Aufsätze und Materialien, Berlin 2005.

Schmitt C., Die Sichtbarkeit der Kirche. Eine scholastische Erwägung, [w:] idem, Die Militärzeit 1915 bis 1919. Tagebuch Februar bis Dezember 1915. Aufsätze und Materialien, Berlin 2005.

Schmitt C., Donoso Cortes in gesamteuropäischer Interpretation, Köln 1950.

Schmitt C., Epoka neutralizacji i apolityzacji, [w:] Rewolucja konserwatywna w Niemczech 19181933, red. W. Kunicki, Poznań 1999.

Schmitt C., Lewiatan w teorii państwa Thomasa Hobbesa, Warszawa 2008.

Schmitt C., Machiavelli. Zum 22. Juni 1927, [w:] idem, Staat, Großraum, Nomos. Arbeiten aus den Jahren 1916-1969, Berlin 1995.

Schmitt C., Pojęcie polityczności, [w:] idem, Teologia polityczna i inne pisma, Kraków 2000.

Schmitt C., Rzymski katolicyzm i polityczna forma, [w:] idem, Teologia polityczna i inne pisma, Kraków 2000.

Schmitt C., Tagebücher. Oktober 1912 bis Februar 1915, Berlin 2005.

Schmitt C., Teologia polityczna. Cztery rozdziały poświęcone nauce o suwerenności, [w:] idem, Teologia polityczna i inne pisma, Kraków 2000.

Schmitt C., Thomas Hobbes / Baruch Spinoza, [w:] idem, Schmittiana. Beiträge zu Leben und Werk Carl Schmitts, t. 7, Berlin 2001.

Schwab G., The Challenge of the Exception. An Introduction to the Political Ideas of Carl Schmitt between 1921 and 1936, Berlin 1970.

Schwab G., The Decision, „Revue Européenne des Sciences Sociales” 1978, nr 44.

Sevilla D., El impacto de San Agustín en Donoso, [w:] La Ciudad de Dios, t. 2, Escorial 1955.

Skarzyński R., Od chaosu do tadu. Carl Schmitt i problem tego, co polityczne, Warszawa 1992.

Staglieno M., Spengler, Thomas Mann, Carl Schmitt, [w:] Sul destino, red. S. Zecchi, Bologna 1991.

Studia nad Autorytaryzmem i Totalitaryzmem 39, nr 1, 2017

(C) for this edition by CNS 
Storme T., Carl Schmitt et le marcionisme. L'impossibilité théologico-politique d'un oecuménisme judéo-chrétien?, Paris 2008.

Strauss L., Uwagi do „Pojęcia polityczności” Carla Schmitta, „Kronos” 2008, nr 3.

Szczech T., Państwo i prawo w doktrynie św. Augustyna, Marcina Lutra i Jana Kalwina, Łódź 2006.

Ściegienny A., Spór Erazma z Lutrem, [w:] Antynomie wolności. Z dziejów filozofii wolności, red. M. Drużkowski, K. Sokół, Warszawa 1966.

Święcicki Ł., Przyjaciel czy wróg? Ernst Jünger w perspektywie „Pojęcia polityczności” Carla Schmitta, [w:] Ernst Jünger (1895-1998). Bojownik, robotnik, anarcha, red. W. Chołostiakow, J. Michalczenia, Olsztyn 2013.

Tietz U., „Antropologischer Ansatz politischer Theorien”. Die Freund-Feind Distinktion von Carl Schmitt, [w:] Carl Schmitt. Der Begriff des Politischen. Ein kooperativer Kommentar, red. R. Mehring, Berlin 2003.

Tucker B., Der Ausnahmezustand. An den Grenzen von Aufklärung und Liberalismus, [w:] Carl Schmitt und die Liberalismuskritik, red. H. Lietzmann, K. Hansen, Opladen 1988.

Villalmonte A., El problema del mal y el pecado original en San Agustín, „Naturaleza y Gracia” 1991, nr 3.

Weimayr M., Carl Schmitt —Sprache der Krise/Krise der Sprache, [w:] Gegen den Ausnahmezustand. Zür Kritik an Carl Schmitt, red. W. Pircher, Wien 1999.

\section{ORIGINS OF CARL SCHMITT’S POLITICAL ANTHROPOLOGY}

\section{Summary}

This text concerns the political anthropology of Carl Schmitt. Schmitt says that man is inherently evil, he is born in evilness. On this thesis he builds their theory of politics and the concept of the authoritarian state. But he nowhere is developing his political anthropology. It does not explain why the man is born evil and does not explain what is the source of this view? The literature about Schmitt's theory proposes three interpretations: Christian inspiration, lecture of the writings of Thomas Hobbes, fear of Bolshevism. The author examines these three interpretations and proposes his own. The political anthropology of Carl Schmitt is the mixture of orthodox St. Augustine's teaching, Hobbes's theory, fear of Communism, perhaps the tribulations of family life.

Keywords: Carl Schmitt, political anthropology, political theory, authoritarianism, dictatorship.

Adam Wielomski

a.wielomski@uksw.edu.pl

Studia nad Autorytaryzmem i Totalitaryzmem 39, nr 1, 2017

(C) for this edition by CNS 